\title{
GETTING CONNECTED: THE MEDIEVAL ORDINAND AND HIS SEARCH FOR TITULUS
}

\author{
Des Atkinson
}

Among the many themes that have been rehearsed for the fifteenth-century English Church, the issue of 'title' for priestly ordinands may seem recondite. However, the study of title has wide implications for the study and understanding of the late medieval clergy. It helps to shed light not just on the workings of the ordination process but also on the struggle to obtain preferment and Church livings that was so critical for the secular cleric. While those men who were part of the elite cadre of the clergy were able to obtain preferment to multiple benefices, others who had more modest careers had to seek security and remuneration in whatever way they could. ${ }^{1}$ The study of title feeds into the debate about the level of venality among the religious houses and the secular clergy, and whether the need to obtain a sustainable income was an overwhelming imperative. The gauntly dismissive view of religious houses as hopelessly corrupt or incompetent has long since been challenged. ${ }^{2}$ The study of title can help to confirm just how secure that reassessment of their reputation can be. In the diocese of Salisbury (the focus of this study) the records of title also provide some highly informative details about the educational status and geographical origins of ordinands. The model of the fifteenth-century Church as one that fostered a more highly educated clergy with a focus around the universities is one that the study of

1 A.B. Emden, A Biographical Register of the University of Oxford to A.D. 1500 (3 vols., Oxford, 1957-9) [hereafter BRUO] and idem, A Biographical Register of the University of Cambridge to A.D. 1500 (Cambridge, 1963) [hereafter BRUC]. A close study of Emden's registers shows clearly how across the century future bishops such as Nicholas Bubwith (BRUO, i. 294-6), John Carpenter (ibid., i. 360-1) and Richard Nykke (BRUC, 430-1) obtained many benefices, some even before they were ordained to the priesthood.

2 See J.A.F. Thomson, The Early Tudor Church and Society, 1485-1529 (1993), 225, who says of the monasteries that they still contained men whose devotion to their way of life evoked a fair measure of respect. See also G.W. Bernard, The Late Medieval English Church. Vitality and Vulnerability before the Break with Rome (New Haven, CT, 2012), 172, where he describes monks and nuns as committed to their vocation. A notable example of a religious house where benefactors sought burial and also endowed its expansion is provided by Mount Grace priory, see Glyn Coppack, "“Make Straight in the Desert a Highway for Our God": The Carthusians and Community in Late Medieval England', in Monasteries and Society in the British Isles in the Later Middle Ages, ed. J.E. Burton and Karen Stöber (Woodbridge, 2008), 168-79. 
title can help to clarify. ${ }^{3}$ The importance of Oxford, with its geographical proximity to the diocese of Salisbury, is reflected in the records of title for the diocese. The engagement of religious houses with the provision of title also illuminates the strong relationship between the secular and regular clergy throughout the century. The later break with Rome and the suppression of the religious houses must have had a very disruptive effect on a long-established process of clerical recruitment. For all these reasons the issue of title is worthy of continuing study, and the source used, that of the ordination records, demands further and more detailed scrutiny. These records often provide the only trace we have of many secular clergy, and the lack of a comprehensive database across England and Wales for the late medieval period frustrates any attempt at a full understanding of these men's ordinations and their early careers. The study of the Church in the period after the death of Archbishop Henry Chichele has lacked that focused narrative developed by historians for the earlier part of the fifteenth century. ${ }^{4}$ One reason for that may be the sparsity or inconsistency of records for the churchmen of this time. It is therefore strange that the comparative wealth of records provided in the bishops' registers for the ordination process has not been more fully exploited.

There is no clear consensus about the real meaning of title for priestly ordinations, nor how it operated in the late medieval period. This essay will discuss the definition and implications of titulus and review the literature and historiography that surrounds it. It uses information captured into a computerised database for ordinands within the diocese of Salisbury to see what patterns emerge and how they illuminate the debate. It will also note some interesting comparisons with two northern French dioceses where significant sequences of ordination records survive from the second half of the century. Title was a proof or guarantee that an ordinand presenting himself for the priesthood, or for one of the two other major orders, had a living whereby he could support himself. ${ }^{5}$ Without a title, the ordaining bishop would be held responsible for the financial support of any priest who had no means. This requirement was first promulgated as a disciplinary canon at the Council of Chalcedon in A.D. 451, and subsequently enshrined in canon law. ${ }^{6}$ The major orders, those of sub-deacon, deacon and priest, represented a major commitment for the aspiring ordinand. It committed him to clerical celibacy, and it also provided the diocesan bishop where he was ordained with a clear need to confirm that he had sufficient financial means. For both parties therefore these ordination ceremonies were highly significant. The scramble to obtain any kind of income, especially for the rank-and-file priest, had to be balanced against the number of men coming forward for ordination. The task of administering all of this fell to the diocesan bishop and his staff, and they were also

3 Vincent Gillespie, 'Chichele's Church: Vernacular Theology in England after Thomas Arundel', in After Arundel: Religious Writing in Fifteenth-Century England, ed. Kantik Ghosh and Vincent Gillespie, Medieval Church Studies, xxi (Turnhout, 2011), 3-42.

4 The difficulties in developing such a narrative were discussed at 'After Chichele: Intellectual and Cultural Dynamics of the English Church, 1443 to 1517', a conference held in Oxford in June 2017 (proceedings yet to be published).

5 For the minor orders up to the level of acolyte there was no requirement in canon law for the provision of title.

6 Conciliorum Oecumenicorum Decreta, ed. Giuseppe Alberigo, Hubert Jedin and Centro di Documentazione (Bologna) (Editio altera, Basle, 1962), 190; Corpus Iuris Canonici, ed. E.A. Friedberg (2 vols., Leipzig, 1879-81), ii. 465. 
charged with ensuring that the aspiring ordinands possessed sufficient education and met the other requirements of canon law. The day-to-day work was normally delegated to one of the bishop's archdeacons, and the ordination ceremonies themselves were often conducted by a suffragan. The final responsibility, however, remained with the diocesan.

\section{Literature and historiography}

The most widely quoted early contemporary reference to title appears in the late fourteenth century, in Passus XIII of Langland's Piers Plowman:

The tytle ye take youre ordres by telleth ye ben avaunsed

And nedeth nat to nyme siluer for masses that ye synge.

For he that toek yow a title sholde take yow wages

Or the bischop that blessed yow and enbaumed youre fyngeres. ${ }^{7}$

Langland's concern here seems to be that priests should not be taking payment for the saying of mass as, given their possession of title, they should already have an income sufficient to meet their needs. Any money they did take should be paid over either to the bishop who ordained them or to the person or institution who provided them with title. However, Langland's lines really do not illuminate the issue of title any further.

Following Langland, reference is then often made to Sir Thomas More's work of 1530, the Dialogue on Heresies, where he writes:

there sholde none be admytted vnto presthed vntyll he haue a tytell of a suffycyent yerely lyuyng eyther of his owne patrymony or otherwyse. Nor at this day they be none otherwyse accepted. Why quod he wherfore go there so many of them a beggynge? Mary quod I for they delude the lawe \& them selfe also. For they neuer haue graunt of a lyuyng that may serue them in syght for that purpose but they secretly dyscharge it ere they haue it or els they could not gete it. And thus the bysshop is blynded by $y^{\mathrm{e}}$ syght of the wrytyng \& the prest goth a beggynge for all his graunt of a good lyuynge and the lawe is deluded. ${ }^{8}$

This passage needs careful evaluation and interpretation. More was writing at the very end of the medieval period, and we cannot infer that what may have been true in 1530 was true in 1430 or 1480 . This work is cast in the form of a dialogue and although the words are put in the mouth of the main protagonist, who is identified as More himself, 'the speaker ... is to some extent a dramatic character, not wholly coterminous with More the living human being'. ${ }^{9}$ We cannot be certain therefore

7 William Langland, Piers Plowman, ed. Elizabeth Salter and Derek Pearsall (York Medieval Texts, 1978), 227. The lines quoted are numbered 103-6 within the Passus.

8 Thomas More, The Complete Works of St. Thomas More. Volume 6, Part I. A Dialogue Concerning Heresies, ed. T.M.C. Lawler, Germain Marc'hadour and R.C. Marius, Yale edn. of the Complete Works of St. Thomas More (New Haven, CT, and London, 1981), ch. 3, book 12.

9 Ibid., 440. 
whether the opinions are More's own, or whether he was using this rhetorical device for other purposes. The overall theme of chapter twelve is described by More in his table for Book 3:

The authour toucheth one specyall prerogatyfe that we haue by a preste be he neuer so bad in that his noughtynes can not take frome vs the profyte of his masse. Whervpon is by the messenger moued a doute whyther it were better to haue fewer preestys and better with fewer masses or mo and worse to haue the mo masses. Whervnto the authour answereth.

More's persona appears to believe that there are indeed too many priests, and that many end up in the houses of lay people where 'by reason whereof groweth amonge no lytell corrupcyon in the prestes maners by $y^{\mathrm{e}}$ conuersacyon of ley people \& company of women in theyr houses'. However, we know that the employment of personal chaplains by gentry and noble families was a long-standing feature of their piety; private chapels had been widely distributed in England by the mid-fourteenth century. ${ }^{10}$ More's discontent may therefore reflect his desire to achieve a more perfect state for both the Church and its priesthood, an aspiration that may have been neither realistic nor achievable. As regards the issue of title, no specific information is offered within the Dialogue beyond a statement of opinion. Thomas More was born, educated (at least until university) and worked in London. ${ }^{11}$ From the registers of the archbishops of Canterbury it is clear that the clergy of London could sometimes be a source of dismay to their superiors. ${ }^{12}$ More's perspective might have been distorted by his metropolitan focus. It is therefore difficult to see the passage quoted above as a definitive contemporary account of the working or failings of this aspect of canon law. In terms of modern scholarship, writers such as H.F. Bennett and A.B. Emden were commenting on the subject of title in the 1950s. Bennett's focus was on the provision by religious houses. For him it was difficult to understand how such institutions were able to assume the extra liability of providing title 'at a time when it is generally agreed that their financial prosperity was waning'. His conclusion was that such titles were little more than nominal, meaning that canonical regulations were not being rigorously observed. ${ }^{13}$ Emden, writing in 1957 while compiling his magisterial register of the students at Oxford before 1500, expressed puzzlement; he described medieval practice with regards to ordinands and their titles as an 'obscure subject' requiring fuller investigation. ${ }^{14}$ Subsequent authors have taken up Emden's call. In her investigations in the diocese of Lincoln, Margaret Bowker concluded that most ordinands took their titles from religious houses, and that this would be the

10 R.N. Swanson, Religion and Devotion in Europe, c.1215-c.1515 (Cambridge, 1995), 123.

11 S.B. House, 'More, Sir Thomas (1478-1535)', Oxford DNB.

12 Archbishop Thomas Bourgchier complained in 1460 of the way the London clergy dressed like laymen in gowns that were open at the front: Registrum Thome Bourgchier, Cantuariensis Archiepiscopi, A.D. 1454-1486, ed. F.R.H. Du Boulay (Canterbury and York Society liv, Oxford, 1957), 92. His successor, Archbishop John Morton, had similar complaints about their dress and general behaviour in 1487: The Register of John Morton, Archbishop of Canterbury, 1486-1500, ed. Christopher Harper-Bill (3 vols., Canterbury and York Society, 1xxv, lxxviii, lxxxix, York, 1987-2000), i. nos. 92, 94.

13 H.F. Bennett, 'Medieval Ordination Lists in the English Episcopal Registers', in Studies Presented to Sir Hilary Jenkinson, ed. James Conway Davies (1957), 29.

14 BRUO, i. p. xxxvii. 
house that was nearest to their place of origin, or at least the nearest house of any size. However, if an ordinand were studying at a university, then he seems to have taken his title from a house close to his place of study. She considered whether there might be a link between the provision of title and the subsequent awarding of a living in the gift of the same house, but in her survey of 112 priests she did not find a single such example. ${ }^{15}$

Writing in 1969, Peter Heath's analysis of the role of examiners in processing candidates for ordination led him to scathing criticism. He accused them of uncanonical and almost cynical haste for accepting title from religious houses that could not possibly have had the means to support such men. The religious houses providing such title were 'among the poorer, if not the poorest, establishments'. ${ }^{16}$ The search by scholars for more evidence on this puzzling topic continued, and in 1983 Jo Moran believed that she had uncovered evidence that titles were not just given but could be bought. She pointed to a will in the Knaresborough court rolls dated 1538 where Thomas Atkinson, yeoman, made the following request:

I wyll that Robert Atkynson, my son, shall have hys fyndyng of my sayd wyffe, either at Yorke or elles where it shalbe thought beste, so that he may folowe the scole unto suche tyme yt he may gette orders and be preiste, and that he shall have his tytle and singynge geyr boughte at the coste of my sayde wyeffe. ${ }^{17}$

Moran's statement that this single will provides 'clear' evidence has, however, been disputed by later commentators. ${ }^{18}$ The date of 1538 is a late one, and it is problematic to assume that this one instance of something being 'boughte' is representative of an entire system. There is also the question of what the exchange of money described here might actually be buying. This subject will be returned to later. Robert Swanson's analysis of 1985 is cautious and more nuanced. He believes that it remains a possibility that ... monastic titles to orders ... were not entirely fraudulent. They could have provided something of a financial safety-net for the unbeneficed clergy. ${ }^{19}$ Swanson tentatively proposed a theory that title may have been provided by the religious house that also examined the candidate for ordination. He was conscious of the fact that nunneries provided a significant proportion of titles, and this is awkward for the examination hypothesis. He also highlighted the speed of the changeover from patrimonial to monastic titles that occurred in the second half of the fourteenth century in both the Lichfield and York dioceses. For Swanson the only acceptable explanation was that the change had occurred with official sanction, 'if not prodding'. ${ }^{20}$

Tim Cooper took up Swanson's examination hypothesis in his study of clergy in

15 Margaret Bowker, The Secular Clergy in the Diocese of Lincoln, 1495-1520, Cambridge Studies in Medieval Life and Thought xiii (Cambridge, 1968), 61-2.

16 Peter Heath, The English Parish Clergy on the Eve of the Reformation (1969), 17.

17 Jo Ann Hoeppner Moran, 'Clerical Recruitment in the Diocese of York, 1340-1530: Data and Commentary', Journal of Ecclesiastical History, xxxiv (1983), 30, n. 52.

18 For example, R.N. Swanson, 'Titles to Orders in Medieval English Episcopal Registers', in Studies in Medieval History Presented to R.H.C. Davis, ed. R.I. Moore and Henry Mayr-Harting (1985), 236, n. 15. Swanson describes Moran's evidence as 'quite inconclusive'.

19 Ibid., 245.

20 Ibid., 241-2. 
the diocese of Coventry and Lichfield. His research in Lancashire showed that title was usually provided by a religious house in the vicinity of the candidate's place of origin. Only a small proportion of titles were provided by more wealthy houses, implying that title did not represent a firm financial guarantee. ${ }^{21}$ There was no evidence in the records of any appeals made by clerks against failed or inadequate titles, a finding which suggests that wholesale fraud is not likely. Cooper therefore concluded that 'the more persuasive argument, albeit largely from the silence of the sources, is that the titles were evidence of an investigative system already undertaken by the time the candidate presented himself for orders'. He suggested that a monastic title may in itself have been no financial guarantee, but just the evidence that the candidate had been deemed to be financially self-sufficient and worthy. ${ }^{22}$

Some general themes emerge from all of this existing scholarship. Title, when provided by a religious house, appears not to be a direct financial guarantee to support poor clergy. Rather, it has the character of a certificate of examination, both into the suitability of a candidate for ordination in terms of background, education and general fitness, and into the financial viability of the aspiring ordinand's case. This would suggest that lying behind the title itself was a process of investigation that led the provider to be satisfied as to the 'real' source of financial support. Scholars also agree that title had a geographic element, with many ordinands being provided by a house in their locality. The question of whether titles were bought does not yield a consensus. Nevertheless, there now seems to be a greater reluctance to regard the process as generally fraudulent. It seems possible that a modest fee may have been payable to the religious house for its trouble, perhaps just a few pence. $^{23}$

\section{The evidence from the}

The registers of the bishops of Salisbury for the fifteenth century provide a rich resource for the investigation of the ordination process. There are no significant gaps in the sequence, and there is consistency in the format and completeness of each set of records. The registers for Robert Hallum (1407-17), Thomas Langton (1485-93) and John Blyth (1493-9) have been edited and published. ${ }^{24}$ The remainder are in manuscript form. ${ }^{25}$ A sampling approach has been taken to process the information from the ordination records within the registers and add it to a computerised database for ease of analysis. The sets of records currently contained within the database are listed in the following table.

21 Tim Cooper, The Last Generation of English Catholic Clergy (Woodbridge, 1999), 21, 24.

22 Ibid., 27.

23 Swanson, 'Titles to Orders in Medieval English Episcopal Registers', 236, n. 15.

24 The Register of Robert Hallum, Bishop of Salisbury, 1407-17, ed. J.M. Horn (York, 1982); The Register of Thomas Langton, Bishop of Salisbury 1485-93, ed. D.P. Wright (Canterbury and York Society, lxxiv, York, 1985); The Register of John Blyth, Bishop of Salisbury 1493-1499, ed. David Wright (Chippenham, 2015).

25 D.M. Smith, Supplement to the 'Guide to Bishops' Registers of England and Wales. A Survey from the Middle Ages to the Abolition of Episcopacy in 1646 (York, 2004), 27-8. Blyth's register has been published since Smith's supplement was produced. 
Table 1: Salisbury ordination records in the computerised database.

\begin{tabular}{lcl}
\hline Date range & $\begin{array}{l}\text { No. of ordination } \\
\text { ceremonies }\end{array}$ & Source \\
\hline Sept. 1409 to Dec. 1410 & 6 & Reg. Hallum \\
Mar. 1418 to Sept. 1420 & 8 & Reg. John Chandler \\
Mar. 1430 to Dec. 1432 & 10 & Reg. Robert Neville \\
Mar. 1450 to Mar. 1452 & 11 & Regs. Aiscough and Beauchamp \\
Feb. 1486 to June 1493 & 25 & Reg. Thomas Langton \\
\hline
\end{tabular}

The database contains records for over 1,400 individuals and the approach adopted in terms of categorising the title for each ordinand is the same as that adopted by Virginia Davis in her study of the diocese of London. ${ }^{26}$ A typical ordination record from Salisbury, taken from the register of Bishop Robert Neville, describes the ceremony that took place on 22 September 1436 in the church of the Dominican friary; it was taken by a suffragan, Bishop Richard of Innis Scattery. On that day fourteen acolytes, twenty sub-deacons, eight deacons and ordained..$^{27}$ Of the priestly ordinands, the first six listed were regu 2 lergy, and for each of the secular clergy that follow their title was clearly stated. Interestingly, there were several men from dioceses other than Salisbury, so there is a distinctly cosmopolitan feel to these registers. The entry for the reads as follows:

\section{Presbiteri}

Frater Henricus Trent, monachus monasterij de Abbotesbury;

Frater Johannes Modeford, monachus monasterij de Schyrborn;

Frater Franciscus de Ytilia, ordinis domus Fratrorum Minorum Sarisbiriensis;

Frater Willelmus Dewke, eiusdem domus professus;

Frater Johannes Kyllesby, eiusdem domus professus;

Frater Walterus Roselemare, domus Fratrorum Minorum Radingensis;

Ricardus Stafford, Fernensis diocesis, ad titulum hospitalis Sancti Johannis Baptiste iuxta Weys' per litteras dimissorias sufficienter dimissus;

Nicholaus Pyttes, Bathoniensis diocesis, ad titulum monasterij de Folda, Exoniensis diocesis, per litteras dimissorias sufficienter dimissus;

Johannes Tabarer, Bathoniensis diocesis, ad titulum monasterij de Athelney eiusdem diocesis, per litteras dimissorias sufficienter dimissus

26 Virginia Davis, Clergy in London in the Late Middle Ages. A Register of Clergy Ordained in the Diocese of London Based on the Episcopal Ordination Lists 1361-1539 (2000). Davis is not specifically concerned with the issue of title, but she provides a concise and useful discussion of the topic in her introduction (pp. 13-14) and in her discussion of her clergy database (pp. 45-6).

27 Wiltshire and Swindon History Centre, Register of Robert Neville (1427-38), D1/2/9, f. 132v. Various suffragans acted on behalf of the bishops of Salisbury at ordination ceremonies during the 15th century. Several were Franciscan friars, such as John Greenlaw, John Chiveley and Robert Windell; several were Dominicans, such as Richard Belmer (probably the same man as Bishop Richard of Innis Scattery), James Blakedon and Simon Elvington. Some of these names are not recorded in The Handbook of British Chronology, ed. E.B. Fryde et al. (3rd edn., 1986), 284-7, although a few had been in the 2nd edn. (1959), 269-71. John Greenlaw, Bishop 'Soltaniensis', was also active as a suffragan in Lincoln and other dioceses: D.M. Smith, 'Suffragan Bishops in the Medieval Diocese of Lincoln', Lincolnshire History and Archaeology, xvii (1982), 26. 
Robertus Karevyle, Sarisbiriensis diocesis, vicarius in choro ecclesie cathedralis Sarisbiriensis, ad titulum stalli sui;...Nicholaus Amyn, Bathoniensis diocesis, ad titulum prioratus de Taunton, per litteras dimissorias sufficienter dimissus;

Johannes Whyte, Exoniensis diocesis, ad titulum Osenye, per litteras dimissorias sufficienter dimissus.

Figure 1 summarises the number of priests ordained in each of the five periods as listed in Table 1.

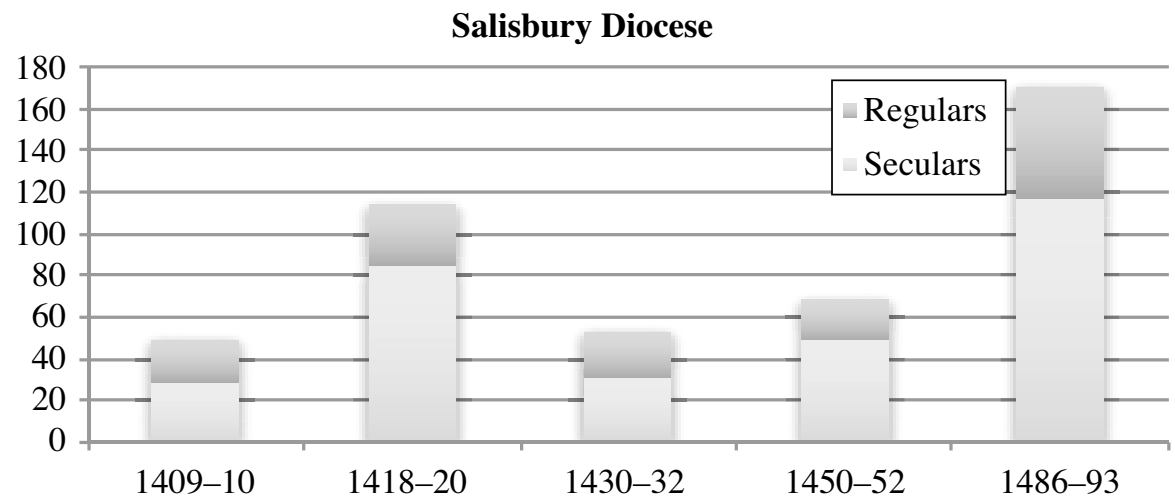

Figure 1: Total numbers of priestly ordinations.

The values on the chart are stacked so, in the period 1409-10, there were forty-nine priests ordained in total, twenty-nine seculars and twenty regulars. Overall, the proportion of secular ordinands was just over two-thirds. ${ }^{28}$ As the periods shown in Figure 1 vary in length, the chart does not indicate how the rate of priestly ordinations differed year on year. That information is given in Figure 2.

The significantly higher rate of ordinations in the period 1418-20 is striking. The temptation is to see a peak coming immediately after the Council of Constance and to attribute it to a post-schism surge in recruitment. There are some signs of such a peak in the more comprehensive numbers for the diocese of London. ${ }^{29}$ Unlike in London, however, the Salisbury figures suggest a flat trend in the number of ordinations for the end of the fifteenth century. ${ }^{30}$ A clearer picture for the latter diocese may emerge as further ordination ceremonies are added to the database. The presence of a high proportion of men from other dioceses coming forward for ordination can be seen in the record from 1436, cited above. The breakdown between such men holding letters

28 That figure is close to the one derived by Virginia Davis. She shows that in the diocese of London in the period 1490 to 1529 there were 1,819 secular ordinands: Davis, Clergy in London in the Late Middle Ages, 31. Although her figures for regular clergy cannot be treated as complete, the number appears to be around 900: ibid., 35-40.

29 Davis's numbers show high rates in the 1370 s and 1410 s, but those in the 1420 s are more subdued. She summarises her figures by decade, with the 1400s a low point, followed by a major surge in the $1410 \mathrm{~s}$. She suggests that the ending of the schism with the election of Pope Martin V may have been a key factor: ibid., 22-3.

30 Ibid., 29. 


\section{Salisbury Diocese}

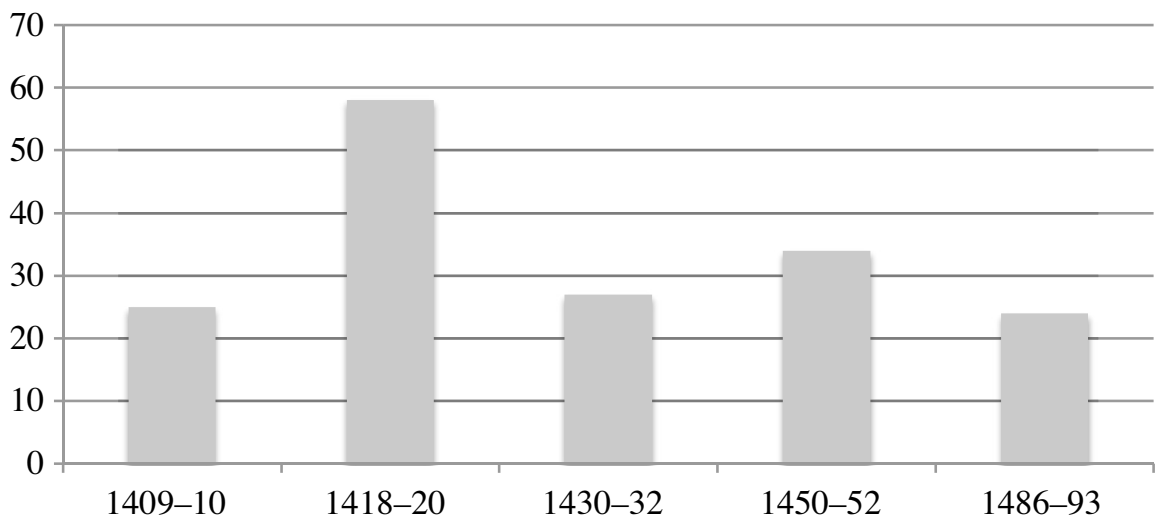

Figure 2: Average number of priests ordained per year

\section{Salisbury Diocese}

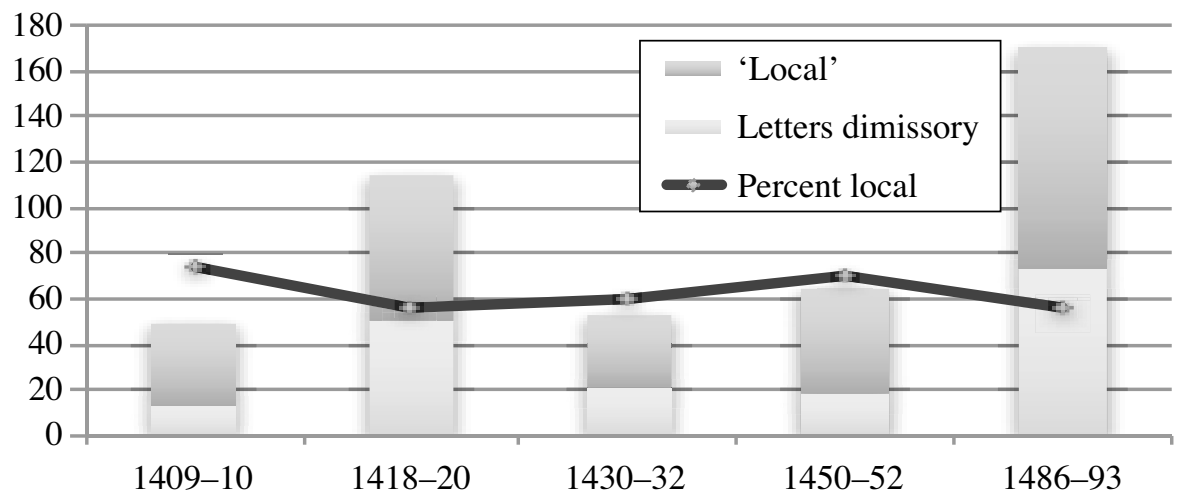

Figure 3: The geographical origins of priestly ordinands

dimissory from their own bishop and the men local to the Salisbury diocese is given in Figure 3.

In general the proportion of local men was between $55 \%$ and $60 \%$. If the decade of the 1400s is taken as an unusual low point in the pattern of ordinations, then the proportion of $74 \%$ for the period 1409-10 may be taken as an anomaly. The question that next arises is where these incomers with title from religious houses were from. About half of the incomers were from dioceses bordering Salisbury, with 20\% from Exeter, 16\% from Bath and Wells, and 10\% from Lincoln. A significant group of dioceses, however, were northern ones, in particular Carlisle, with $8 \%$, and York, with $10 \%$. Taking Carlisle in particular, the list of religious houses that granted titles (see Table 2 below) shows a notable pattern. 
Table 2: List of religious houses granting title to the aspiring priests from Carlisle, 1486-93.

\begin{tabular}{ll}
\hline Religious house & Number of instances \\
\hline St. Frideswide priory & 2 \\
Osney abbey & 1 \\
Bicester priory & 1 \\
Poughley priory & 1 \\
Reading abbey & 2 \\
Nocton Park priory & 1 \\
Shap abbey & 1 \\
\hline
\end{tabular}

With the exception of Shap abbey in Cumberland and Nocton Park priory in Lincolnshire, all of the houses were either in or close to Oxford. The suggestion, therefore, is that these Carlisle men were studying at Oxford and hence sought title from a local institution. Many of the ordination ceremonies of Thomas Langton's Salisbury episcopacy took place in Ramsbury, a little over thirty miles south-west of Oxford. This may provide a partial explanation as to why the Carlisle men sought ordination in the diocese of Salisbury rather than making the long journey north to Lincoln. However, the bishop of Lincoln did also hold ordination ceremonies in the chapels of Oxford colleges, so a local ceremony was possible. ${ }^{31}$ The predominance of the religious houses as providers of title is clear from the ordination records. The average proportion of titles provided by them was greater than $76 \%$ by the period 1486-93. In contrast, the proportion of title provided by benefice or any other category was less than $6 \%$. The focus for the rest of this essay will therefore be on those religious houses and on what patterns of patronage they display. The pattern of title provision in the Salisbury diocese changed in the course of the century. Table 3 shows the top five title-givers during the period 1418-20. The fourth column in the table shows the net value of the house as given in the Valor Ecclesiasticus of $1535 .{ }^{32}$

Table 3: The top five providers of title to secular priestly ordinands in the Salisbury diocese in $1418-20$.

\begin{tabular}{lllll}
\hline House & Diocese & No. of titles granted & Net valuation & Religious order \\
\hline Bodmin & Exeter & 5 & $£ 270$ & Augustinian \\
Ivychurch & Salisbury & 4 & $£ 122$ & Augustinian \\
Montacute & Bath and Wells & 3 & $£ 456$ & Cluniac \\
St. Germans & Exeter & 3 & $£ 227$ & Augustinian \\
Bradenstoke & Salisbury & 2 & $£ 212$ & Augustinian \\
\hline
\end{tabular}

31 See, for example, BRUO, ii. 1020 for the ordination in 1488 of John Jolyffe in Durham College chapel; also ibid., 1327 for the ordination in 1491 of Thomas Mugwurthy in New College chapel.

32 The values are taken from Alexander Savine, English Monasteries on the Eve of the Dissolution (Oxford, 1909), appendix, 269-88. 
It is noteworthy that less than half of the titles shown in this table were provided by houses within the Salisbury diocese. The predominance of Augustinian houses is clear, and this would seem to reflect the level of engagement of that order with the secular clergy and its high level of patronage of parish churches. ${ }^{33}$ The value of the houses is also of note: these were not the very poorest, and Montacute in particular was certainly into the middle range in terms of income. By the end of the period the emphasis had shifted more towards houses near Oxford.

Table 4: The top five providers of title to secular priestly ordinands in 1486-93.

\begin{tabular}{lllll}
\hline House & Diocese & $\begin{array}{l}\text { Number of } \\
\text { titles granted }\end{array}$ & Net valuation & Religious order \\
\hline Osney abbey & Lincoln & 10 & $£ 654$ & Augustinian \\
St. Frideswide priory & Lincoln & 5 & $£ 222$ & Augustinian \\
Malmesbury abbey & Salisbury & 5 & $£ 803$ & Benedictine \\
Cerne abbey & Salisbury & 4 & $£ 515$ & Benedictine \\
Taunton priory & Bath and Wells & 3 & $£ 286$ & Augustinian \\
\hline
\end{tabular}

Once again the Augustinian houses feature strongly, with the two Oxford houses heading the list. The home diocese was represented by two Benedictine houses, both of which belonged to the middle rank by income. If we look in greater detail at individual houses, more useful insights emerge. In the period 1418-20 the leading house (Bodmin priory) provided its five titles to men from the local diocese of Exeter. The same had been true for the top provider in the years 1409-10 (the hospital of St. John at Wells, which had provided three titles to men from Bath and Wells), and in the period 1430-2 Ivychurch priory in the Salisbury diocese had provided its two titles to local men. By the period 1486-93 the picture had become very different. The ten titles awarded by Osney abbey went to ordinands from the dioceses of St. Andrews, Carlisle, Lincoln, Durham, Salisbury (two), St. David's, Norwich, Coventry and Lichfield, and Exeter. Unfortunately there are references in Emden's biographical register for only two of these, and both entries are very brief. ${ }^{34}$ St. Frideswide's five titles were provided to men from Exeter, Carlisle (two), Salisbury and Worcester. None of them have entries in Emden's register. It may be that these men were studying at Oxford but had no intention of supplicating for a degree. ${ }^{35}$ From the database it is possible to list those men who were graduates at the time of their priestly ordination and who were provided with their titles by religious houses. These are listed in Table 5.

33 The Regular Canons in the Medieval British Isles, ed. J.E. Burton and Karen Stöber (Turnhout, 2011), 3.

34 The entry for David Cadogan (BRUO, i. 337) confirms that he came from the diocese of St. David's and states that he went on to become the vicar of Longstock, Hants. The entry for William Bell (BRUO, i. 162) confirms that he came from the Carlisle diocese; he was chaplain at Queens College in $1492-4$.

35 Possibly half or more of the students at Oxford never achieved a formal degree qualification: Ralph Evans, 'The Number, Origins and Careers of Scholars', in The History of the University of Oxford, Vol. 2, Late Medieval Oxford, ed. J.I. Catto and Ralph Evans (Oxford, 1992), 497. 
Table 5: The graduates within the database who were provided with title by religious houses for their ordination to the priesthood.

\begin{tabular}{|c|c|c|c|c|}
\hline Name & Diocese & $\begin{array}{l}\text { Degree } \\
\text { (where known) }\end{array}$ & $\begin{array}{l}B R U O \\
\text { reference }\end{array}$ & $\begin{array}{l}\text { House providing } \\
\text { title }\end{array}$ \\
\hline Henry Bryan & Salisbury & M.A. & i. 290 & $\begin{array}{l}\text { Malmesbury abbey } \\
\text { (Benedictine) }\end{array}$ \\
\hline Thomas Mychell & Salisbury & & ii. 1273 & $\begin{array}{l}\text { Bradenstoke priory } \\
\text { (Augustinian) }\end{array}$ \\
\hline John Jenyn & Bath and Wells & & ii. $1015-16$ & $\begin{array}{l}\text { Muchelney abbey } \\
\text { (Benedictine) }\end{array}$ \\
\hline John Jolyff & Salisbury & M.A. & ii. 1020 & $\begin{array}{l}\text { Milton abbey } \\
\text { (Benedictine) }\end{array}$ \\
\hline William Fowell & Exeter & & ii. 713 & $\begin{array}{l}\text { Plympton priory } \\
\text { (Augustinian) }\end{array}$ \\
\hline Thomas Mugwurthy & Exeter & $\begin{array}{l}\text { B.C.L. and } \\
\text { B.Cn.L. }\end{array}$ & ii. 1327 & $\begin{array}{l}\text { St. Germans priory } \\
\text { (Augustinian) }\end{array}$ \\
\hline Thomas Hede & Worcester & $\begin{array}{l}\text { B.C.L., later } \\
\text { D.C.L. }\end{array}$ & ii. 900 & $\begin{array}{l}\text { Torksey priory } \\
\text { (Augustinian) }\end{array}$ \\
\hline William Asshe & Salisbury & B.A. & $\begin{array}{l}\text { None (nor } \\
\text { in } B R U C \text { ) }\end{array}$ & $\begin{array}{l}\text { Amesbury priory } \\
\text { (Benedictine nuns) }\end{array}$ \\
\hline
\end{tabular}

With the exception of Thomas Hede, all these men were provided with title by a house in their home diocese. Hede's title came from Torksey priory, a house for Augustinian canons that lay approximately twelve miles north-west of Lincoln. Torksey was a very poor house with a net value in the Valor of a little over $£ 13 .{ }^{36}$

One final aspect of the provision of title by religious houses in the Salisbury registers that shows an interesting pattern relates to the number of houses listed within each ceremony. Any one house could provide title for more than one priestly ordinand, and a house that had a strong desire to profit from this process might offer title to some or all of the ordinands presenting themselves. However, the information given in Figure 4 below suggests that, at most ceremonies, there was a broad spread of houses offering title. The chart relates to the number of men who received title from a religious house and were being ordained as priest at each ceremony, and it also shows the number of religious houses providing title to those men.

Thus, where the two figures are the same, then each religious house was providing title to one man only. For example, at the ceremony held on 18 September 1490 eight men were ordained as priest and eight different houses provided title: Biddlesden abbey (Buckinghamshire, Cistercian), Bradenstoke priory (Wiltshire, Augustinian canons), Bruern abbey (Oxfordshire, Cistercian), Felley priory (Nottinghamshire, Augustinian canons), Kingswood abbey (Gloucestershire, Cistercian), Malmesbury abbey (Wiltshire, Benedictine), Strata Marcella abbey (Powys, Cistercian) and Tarrant abbey (Dorset, Cistercian nuns). It is intriguing how, at this ceremony, the Cistercian houses should be so well represented. ${ }^{37}$ One of the earlier ceremonies on

36 Savine, English Monasteries on the Eve of the Dissolution, 277.

37 The role of the Cistercians in the support of the secular clergy has not been widely explored; the Salisbury records suggest that further study might be fruitful. Recent work, although acknowledging that the Cistercians had an obligation to the world and were dependent on it, does not provide any 


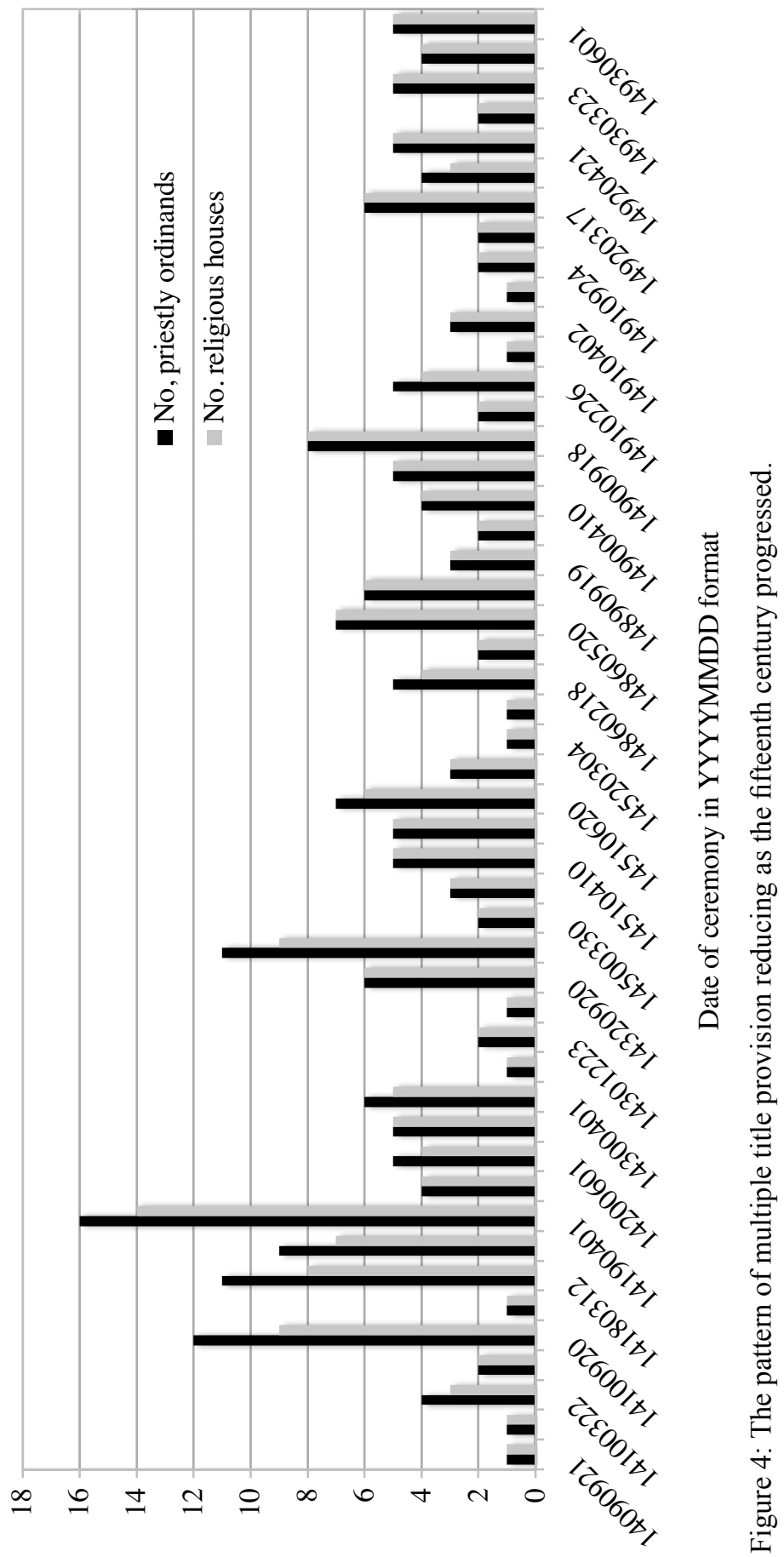


the chart, that held on 12 March 1418, had a different pattern in that, of the eleven men ordained priest who had title from a religious house, four received title from the Cornish Benedictine house of Bodmin priory. The other seven men received title from seven different houses. This ceremony is unusual, as it is the only one of the forty-nine on the chart where a single house provided title to so many men. In all other cases no house provided more than two titles to priestly ordinands at a single ceremony. One pattern that does emerge quite clearly is how the provision of multiple titles was relatively common earlier in the sequence, but absent for the later ceremonies. That may represent a maturing of the title process, with an increasing number of houses willing and able to provide title so that ordinands could be served by one of their local houses.

\section{The picture from northern France}

The surviving coverage of medieval church records for northern France is patchy; however, the work of Vincent Tabbagh has shown that there are some significant clusters of surviving registers of tonsure and ordination for the dioceses of both Sées and Sens. ${ }^{38}$ All of these records have been examined, revealing a major difference from England in the way that titles were recorded. In the French registers the title for secular ordinands were, in a significant proportion of cases, listed simply as ad titulum approbatum. Clearly the scribe or registrar felt it necessary to show that there was a title so that each ordinand met the requirements of canon law, but he did not see a requirement to record the details of which religious house, patron or other patrimony was involved. The terseness of these records can be interpreted in a number of different ways. It may be that these registers were not the document that the ordaining bishop expected to use if a subsequent question arose as to a candidate's title. If that were the case then it does seem odd that no instances of any such supporting records appear to have survived. If the surviving registers were the only record of the ordination then this may indicate that the French bishops faced few if any problems with respect to title, and did not often feel the need to record any more detail. Of course, if the whole issue of title is regarded as effectively a fraud and of no real meaning, then the seemingly perfunctory brevity of so many of the entries might be seen as evidence to support that viewpoint. Yet it is a puzzle that the English registers for Salisbury, Exeter, Canterbury and elsewhere consistently spell out the title details in full, whereas, in these two French dioceses, they do so only on occasion.

One other striking difference between the French and English ordination records is the detailed listing of tonsurati in the French registers. Among the English dioceses it is unusual to see any such list. There is a suggestion that the desire among the French to take the tonsure and have it recorded was a wish to gain status and

significant insight into this aspect of the Cistercians' patronage: J.E. Burton and Julie Kerr, The Cistercians in the Middle Ages (Woodbridge, 2011), 200.

38 Vincent Tabbagh, 'Effectifs et Recrutement Du Clergé Séculier Français à La Fin Du Moyen Age', in Le Clerc Séculier Au Moyen Âge. XXIIe Congrès de La S.H.M.E.S. (Amiens, Juin 1991) (Paris, 1993), 182, n. 2. The registers for Sées are held at the Archives Départementales de l'Orne in Alençon (1 G 37-40) and cover the following years: 1412-19, 1443-54, 1463-84 and 1485-99. Those for Sens are held in the Archives Départementales de l'Yonne in Auxerre (G5), and cover the following years: 1457-8, 1469-73, 1484-91 and 1490-9 (G 205-7). 
protection from the civil law. ${ }^{39}$ That is a plausible explanation and would reflect a need on the part of the French episcopal clerks to preserve a faithful record of each ordination ceremony. It would seem odd, therefore, that the same scribes chose not to include a full and detailed record of title when it came to priestly ordinations.

\section{Conclusions}

Some direct and illuminating findings can be brought out by a focus on this study of the diocese of Salisbury. There are, however, conclusions of a wider significance that also flow from the Salisbury information. The influence of geography on the provision of title to secular candidates by religious houses shows itself strongly, particularly in what might be described as the gravitational effect of Oxford. Religious houses such as St. Frideswide and Osney appear to be providing title to men studying at the university, although it is noteworthy that most of them do not appear to have gone on to become graduates. Perhaps just as noteworthy are the houses that are absent from the list. The nearby wealthy abbey of Abingdon, for example, did not provide a single title in the period $1486-93 .{ }^{40}$ Nevertheless, it had certainly been in the business of providing patronage to Oxford men such as John Morton, who received his first rectorship (the church of Shellingford, Berkshire) from the abbey in June $1453 .{ }^{41}$ Other Oxford jurists and contemporaries of Morton also enjoyed the benefices that Abingdon provided. ${ }^{42}$ Given the abbey's wealth it is perhaps not surprising that it did not need to cater for the title 'trade' (if we assume that some kind of fee was required of men seeking title). The titles provided to the Oxford men by Osney and other houses physically close to Oxford show a cosmopolitan approach that reflects the students' differing geographical origins. By contrast and in general, the more distant houses provided title to candidates from their local diocese. The Augustinian order was in the forefront for providing titles to Salisbury men. This theme runs throughout the century, although in the period after 1486 the Benedictine houses were a significant presence, albeit at a lower level. Given the numerical dominance of the Augustinian houses, these facts are perhaps not surprising, and their involvement in secular matters may also be an important influence. ${ }^{43}$ The view that titles were provided by only the poorest houses is not supported by the evidence from Salisbury. Although some poorer houses such as Torksey and Ivychurch do appear on the list, many of the others were well into the middle rank in terms of wealth (Osney, Malmesbury, Montacute and Cerne, for example). However, no wealthy houses (those with a net income of over $£ 1,000$ in 1535) feature. This suggests that

39 J.M. Hayden and M.R. Greenshields, Six Hundred Years of Reform. Bishops and the French Church, 1190-1789 (Montreal, 2005), 51.

40 The abbey was valued at almost $£ 1,900$ net in the Valor Ecclesiasticus: VCH Berkshire, ii. 51-62.

41 BRUO, ii. 1318-20.

42 The following were all graduates in canon law: William Parker, who gained at least four benefices, the first in 1452 (BRUO, iii. 1427); Richard Pede in 1448 (ibid., iii. 1449-50); John Stretton (in 1458), who went on to become the chancellor of the bishop of Salisbury in 1460 (ibid., iii. 1805); Thomas Swyft in 1453 (ibid., iii. 1834); Richard William in 1454 (ibid., iii. 2050); and John Wylley in 1452 (ibid., iii. 2116).

43 Of almost 900 religious houses in England, over 270 were foundations of regular canons: C.H. Lawrence, Medieval Monasticism. Forms of Religious Life in Western Europe in the Middle Ages (2nd edn., 1989), 167. 
the income that may have come from furnishing titles was modest, but was enough to justify whatever work was required. The fact that such income was spread across many individual houses does not suggest any particular greed or venality among the monastic institutions that provided this service. There is no evidence of any one house attempting to derive an undue proportion of the income.

The ordaining bishops in Salisbury appear to have been happy to accept the validity of title even where the ordinand was from another diocese and perhaps had received title from a house in a third diocese. Such an attitude was certainly not unique to Salisbury, and even the archbishop of Canterbury did the same. ${ }^{44}$ The wide acceptance of both title and of letters dimissory could be interpreted as a sign that ordination procedures had become slack, and that such records were treated simply as routine administrative objects. Yet a wholly contrary viewpoint would be that the process of administering ordinands and their qualifications was working well across the country; the documents from other dioceses were accepted because they represented a trusted assurance as to the qualities and bona fides of the candidates. In the Salisbury diocese very few of the providers of title were nunneries. If they were involved in an administrative process to vet candidates, then it is interesting to speculate as to who would carry out such an examination. Each female house had one or more chaplains to serve the needs of the community; ${ }^{45}$ they may not have had sufficient seniority or authority to conduct such an examination, yet it is open to question whether a prioress or abbess would carry out such a procedure with a male stranger, even if he were already a clerk. The overall conclusions that may be drawn from the Salisbury evidence support the views on title put forward by Tim Cooper. From a financial perspective it seems likely that title was not a direct promise of support by a religious house. It was probably a form of certification to confirm that the ordinand had provided evidence or sufficient explanation as to how he would support himself. This administrative process would surely have involved the payment of a small fee, hence the payment described by Jo Moran. The idea that such payment was effectively a bribe and that the whole system was fundamentally corrupt is, however, at best an exaggeration and, more probably, a gross distortion of the true process. The sudden switch to the predominant provision of title by religious houses in many dioceses would support this hypothesis. It would represent a new administrative layer on top of an existing pattern of patronage. It would also ease the administrative burden on the archdeacon who was assisting the bishop's preparations for each ordination ceremony. ${ }^{46}$ The examination of the financial status of the ordinand would have taken place alongside the verification of the other canonical requirements such as education and legitimacy of birth. To suggest that this system

44 Register of John Morton, Archbishop of Canterbury, ed. Harper-Bill, p. xiv.

45 For example, at the Augustinian nunnery of Lacock abbey in 1536 there were four chaplains and a clerk to support the seventeen nuns: H.M. Chew, 'Houses of Augustinian Canonesses: Abbey of Lacock', VCH Wiltshire, iii. 309). At the Cistercian nunnery of Tarrant Kaines, in addition to any chaplains dedicated to the direct service of the house, there is evidence in the 14th century that a series of chaplains and priests were endowed to provided obituary services for their benefactors: 'House of Cistercian nuns: The Abbey of Tarrant Kaines', VCH Dorset, ii. 87-90.

46 This would not have been the only task delegated to religious houses. The collection of the religious tenth was delegated to various priors and abbots by the bishops of Salisbury and Exeter, among others: Register of Robert Hallum, ed. Horn, no. 1060; The Register of Edmund Lacy, Bishop of Exeter, 1420-1455, ed. G.R. Dunstan (5 vols., Torquay, 1963-72), iv. 248; Register of Thomas Langton, ed. Wright, no. 437. 
was perfect would of course be nonsense. The view expressed by Sir Thomas More that bishops were being fooled by the system may well have been true in some cases, and that perception may have become distorted among contemporary commentators, especially in the hothouse atmosphere of the diocese of London. In the registers for the English bishops we see a conscientious desire to record which religious houses were providing title. By contrast, those northern French registers that survive suggest in many cases that the simple record that an approved title had been provided was enough to satisfy the authorities' interpretation of the canonical requirements.

Stepping away from the immediate context of the Salisbury database, some of the implications of this study suggest that the re-examination and redefinition of the Church, especially for the second half of the fifteenth century, need to continue. The records from Salisbury provide further evidence that the standard of education among the clergy was being raised across this period. The records from Norwich have already indicated as much. ${ }^{47}$ However, what the Salisbury records also show is that men were clearly still going to Oxford for periods of study that did not lead to the award of a degree. This less formalised aspect of the life of the university was also paralleled by the continuing existence of inns and halls where many students were still accommodated, despite the development of the new colleges. The Salisbury evidence also suggests that the relationship between the regular and secular clergy continued to be a very close one, both in the context of the universities and beyond. The religious houses, together with other ecclesiastical corporations, had the right of presentation to approximately one-third of all the benefices across England. ${ }^{48}$ The value of those livings varied and, especially for the smaller male houses and for many of the nunneries, their value was well below that of the prebendaries associated with the cathedrals, collegiate churches and other institutions. ${ }^{49}$ Finally, the provision of title provides one of the earliest indicators for the subsequent career of priestly ordinands. Those who were destined for high positions in the Church were normally able to provide title to a benefice. By contrast, the men who would make up the rank-and-file clergy nearly always held their title from a religious house or, very occasionally, a secular patron. That men could and did obtain benefices before ordination to the priesthood was a reflection of their standing among the various patrons who helped launch their ecclesiastical careers. The issue of title is therefore one that repays close study and needs to be given a much fuller and more comprehensive assessment across the whole of the late medieval English Church.

47 Norman Tanner, 'The Reformation and Regionalism: Further Reflections on the Church in Late Medieval Norwich', in Towns and Townspeople in the Fifteenth Century, ed. J.A.F. Thomson (Gloucester, 1988), 129-47. See especially p. 137, where the proportion of graduate clergy increased from $8 \%$ in the period $1370-1449$ to $32 \%$ in the period $1450-99$ and $42 \%$ in $1500-32$.

48 Christopher Harper-Bill, The Pre-Reformation Church in England 1400-1530 (revised edn., Harlow, 1996), 45.

49 For example, the Taxatio database (https://www.hrionline.ac.uk/taxatio/forms) accessed 11 Dec. 2017, shows how the value in the late 13th century of the Salisbury cathedral prebend of Bedwyn was $£ 50$ p.a. Meanwhile, the Cistercian nunnery of Tarrant in the same diocese held the living of Woodyates with a value of $£ 4$ p.a.; the stipendiary clerk whom it placed in that church would therefore have received a very modest income. There is little reason to suppose that the gap between the two livings was significantly different by 1400 or 1450 . 